NEW LEGENDS OF ENGLAND 
THE MIDDLE AGES SERIES

Ruth Mazo Karras, Series Editor

Edward Peters, Founding Editor

A complete list of books in the series is available from the publisher. 


\title{
NEW LEGENDS OF ENGLAND
}

\author{
Forms of Community in \\ Late Medieval Saints' Lives
}

\section{CATHERINE SANOK}

\section{PENN}

UNIVERSITY OF PENNSYLVANIA PRESS 


\title{
Copyright () 2018 University of Pennsylvania Press
}

All rights reserved. Except for brief quotations used for purposes of review or scholarly citation, none of this book may be reproduced in any form by any means without written permission from the publisher.

\author{
Published by \\ University of Pennsylvania Press \\ Philadelphia, Pennsylvania 19104-4112 \\ www.upenn.edu/pennpress \\ Printed in the United States of America on acid-free paper \\ 10988766543321 \\ Library of Congress Cataloging-in-Publication Data \\ ISBN 978-0-8122-4982-8
}


For my mother, sister, and brothers, and in memory of my father 
This page intentionally left blank 